\title{
Investigation of Middle School Students' Self-Efficacy Perceptions of Visual Mathematics Literacy and Perceptions of Problem-Solving Skill*
}

\author{
Furkan ÖZDEMIR $^{* *} \quad$ Murat DURAN ${ }^{* * *} \quad$ Abdullah KAPLAN $^{* * * *}$
}

Received: 03 February 2015

Accepted: 20 October 2016

\begin{abstract}
The purpose of this research is to examine the relationship between self-efficacy perceptions of visual mathematics literacy and perceptions of problem-solving skill of middle school students. Students' self-efficacy perceptions of visual mathematics literacy are determined with a scale developed by Bekdemir and Duran (2012); and, an inventory, developed by Serin, Bulut Serin and Saygl1 (2010), was administered to establish their perceptions towards problem-solving skill. Scales were applied on 338 randomly selected middle school students studying on $3^{\text {rd }}$ and $4^{\text {th }}$ grades of three state schools including one from Kars and two from Erzurum provinces. According to the results of the research, there is a positive directional, low and significant correlation between self-efficacy perception of visual mathematics literacy and perception of problem-solving skill. About $\% 9$ of the differentiation in perception of problem-solving skill of students originate from self-efficacy perception of visual mathematics literacy. Selfefficacy perceptions of visual mathematics literacy of students significantly differ on gender, in favor of girls. Howewer students' perceptions of problem-solving skill did not significantly differ on gender.
\end{abstract}

Keywords: Perception of visual mathematics literacy, perception of problem-solving skill, middle school students

\section{Extended Abstract}

Purpose and Significance: It is known that the solution of mathematical problems in the world today is not only related to self-confidence of individuals, but also in contact with the discovery of mathematical language (Akkaya \& Memnun, 2012). Therefore, the competent mathematical language is considered to require a good level of mathematical literacy (Colak, 2006). The same situation can be said that correlates with visual mathematics literacy because the integration between different disciplines to provide meaningful learning in education matters (Calik \& Capa Aydin, 2014). Similar to modelling process; in the process of problem-solving, students try to understand the problem at first. Then, they design a mental model for problem-solving. Finally, they display a visual quality about problems by writing them down (Baran, Topan, Bozkus \& Gunduz, 2014). In this way, a successful conclusion of the problem-solving process is exhibited intended for the visual mathematics literacy. In the literature, the visual

\footnotetext{
* A part of this study was published as a short summary in the XI. National Science and Mathematics Education Congress (Cukurova University, 11-14 September 2014, Adana, Turkey).

** Corresponding Author: Research Assistant, Ataturk University, Erzurum, Turkey, furkanozdemir24@gmail.com

**** Teacher, Suluova Ataturk Secondary School, Amasya, Turkey, denizyildizi2805@ hotmail.com

**** Prof. Dr., Ataturk University, Erzurum, Turkey, akaplan@ atauni.edu.tr
}

\section{Citation Information}

Özdemir, F., Duran, M., \& Kaplan, A. (2016). Ortaokul öğrencilerinin görsel matematik okuryazarlığ özyeterlik algıları ile problem çözme beceri algılarının incelenmesi. Kuramsal Eğitimbilim Dergisi [Journal of Theoretical Educational Science], 9(4), 532-554. 
mathematics literacy is defined as visualization of daily problems in contrast of evaluation of spatial knowledge as mathematical form (Bekdemir \& Duran, 2012). The correlations between visual objects are much easier to understand through visual mathematics literacy which has an indispensable position in daily life and mathematics education (Tutkun, Erdogan, \& Ozturk, 2014). Dynamic geometry softwares such as Geogebra, Sketchpad and Geospace used in technology-based mathematics education aim to draw interactive geometric objects and shapes and helps students with understanding and analyzing (Bingolbali, 2013). Similarly, symbolic calculation softwares such as Derive, Matlab and Converge allow the visualization of mathematical expressions related to limit, derivative, integration and series (Baki, 2002).

The visualization activities carried out for the development of visual mathematics literacy increase students' achievement as affect positively their interests, motivations and course participation (Saha, Ayub, \& Tarmizi, 2010). Zimmermann (1991) drawn attention to the visual mathematics literacy stated in order to consider successful and understand conceptual a course of analysis should be considered in the visual dimension of issues. PISA (International Student Assessment Project) carried out by the OECD (Organization for Economic Cooperation and Development) in visual mathematics literacy area is concerned with solutions to everyday problems involving mathematical concepts related images of students (OECD, 2007). Also, technology based software programs produced and computer based middle school programs are being developed related to visual mathematics literacy in countries such as America and Israel (Duran \& Bekdemir, 2013). The purpose of this study is to determine whether the relationship between self-efficacy perceptions of visual mathematics literacy and perceptions of problem-solving skill of middle school students.

Method: Screening model in this study is based on the adoption of quantitative research approaches. The sample of the study is 338 randomly selected students including 183 girls and 155 boys studying on 3rd and 4th grades of middle state schools in the province one of Kars and two of Erzurum cities in the first semester of 2013-2014 academic terms. Data tools of the study are "Visual Mathematics Literacy Self Efficacy Perception Scale" developed by Bekdemir and Duran (2012) with "Problem Solving Inventory for Children" developed by Serin, Bulut Serin and Saygili (2010). Visual Mathematics Literacy Self Efficacy Perception Scale has five points likert type and 38 consist of items. Scale is rated as "always", "often", "sometimes", "rarely" and "never". The Cronbach Alpha reliability coefficient of scale is calculated as .94 and that value is determined to be .93 in this study.

Problem Solving Inventory for Children has five points likert type and 24 consist of items. In addition, this inventory consists of three sub-factors. This sub-factors are called as confidence in the problem-solving skill, self-control and avoidance. Factor named confidence in the problem-solving skill corresponds to self confidence in face of problems, not to abandon and stability. Factor named self-control states self-manage in face of problems, more autonomous behavior, developing new ideas and the dominance 
of the internal controlled properties. Factor named avoidance states procrastination, ignoring, inability to confront rather than solving problem when faced with a problem and the heavy press of the trend away from the real problem. Scale is rated as "always", "often", "sometimes", "rarely" and "never". The Cronbach Alpha reliability coefficient of scale is calculated as .80 and that value is determined to be .79 in this study. Descriptive and forecasted statistics methods are used to analyze the data.

In this study, arithmetic mean and standard deviation are used as descriptive sense to determine the level of self-efficacy perceptions of visual mathematics literacy and perceptions of problem-solving skill of middle school students. Ranges of arithmetic mean are calculated by taking into consideration the formula showed "series width / made to the group number" in determining the level of self-efficacy perceptions of visual mathematics literacy and perceptions of problem-solving skill of middle school students. The range of arithmetic mean used in evaluation is given "1.00 to $1.80=$ Never, not ever," "1.81 to 2.60 = Rarely, unusual", "2.61 to $3.40=$ Sometimes, occasional", "3.41-4.20= Often, frequently" and "4.21 to $5.00=$ Always, routinely" in the form.

Independent sample t-test is used as forecasted sense to determine whether there is a difference according to gender between self-efficacy perceptions of visual mathematics literacy and perceptions of problem-solving skill of middle school students. In addition, Pearson Product Moment Correlation Analysis is used to determine whether there is a significant relationship between the levels of self-efficacy perceptions of visual mathematics literacy and perceptions of problem-solving skill of middle school students. Obtained for this relationship, simple linear regression analysis is used to determine whether perception of problem-solving skill is meaningfully predicted selfefficacy perceptions of visual mathematics literacy.

Results: In the result of the examination in order to answer the first sub-problem of the study, "often" has been to be level for perceptions of problem-solving skill of students. So, students have a perception of problem-solving skill above mean. When examining the opinions of the sub-factors, "often" has been to be level in the sub-factors of confidence in the problem-solving skill and avoidance. But, "Sometimes" has been to be level in the sub-factor of self-manage. Accordingly, middle school students find themselves sufficient to solve the problem.

In the result of the examination in order to answer the second sub-problem of the study, "often" has been to be level for self-efficacy perceptions of visual mathematics literacy of students. Based on this finding, it can be said that self-efficacy perceptions of middle school students are over the medium levels in visual mathematics literacy. In the result of the examination in order to answer the third sub-problem of the study, the scores of self-efficacy perceptions of visual mathematics literacy of students have come different meaningfully according to the gender in favor of girls. On the other hand, the scores of perceptions of problem-solving skill of students have not come different meaningfully according to the gender. 
Discussion and Conclusions: Finally, investigations were carried out to find the answers to the fourth and fifth sub-problems of the study. Accordingly, there is a positive directional, low and significant correlation between self-efficacy perceptions of visual mathematics literacy and perceptions of problem-solving skill of middle school students. Furthermore, perceptions of problem-solving skill and self-efficacy perceptions of visual mathematics literacy of middle school students' rate is about $9 \%$ each statement. 


\title{
Ortaokul Öğrencilerinin Görsel Matematik Okuryazarlığı Özyeterlik Algıları ile Problem Çözme Beceri Algılarının İncelenmesi*
}

\author{
Furkan ÖZDEMIR** \\ Murat DURAN ${ }^{* * *}$ \\ Abdullah KAPLAN ${ }^{* * * *}$
}

Makale Gönderme Tarihi: 03 Şubat 2015

Makale Kabul Tarihi: 20 Ekim 2016

\begin{abstract}
ÖZ: Bu araştırmanın amacı, ortaokul öğrencilerinin görsel matematik okuryazarlığı özyeterlik algıları ile problem çözme beceri algıları arasındaki ilişkiyi incelemektir. Öğrencilerin görsel matematik okuryazarlığı özyeterlik algıları Bekdemir ve Duran (2012) tarafindan geliştirilen ölçekle belirlenmiştir. Öğrencilerin problem çözme beceri algıları ise Serin, Bulut Serin ve Saygılı (2010) tarafından geliştirilen envanterle belirlenmiştir. Ölçekler Kars ilinden bir ve Erzurum ilinden iki olmak üzere üç devlet okulunun ortaokul 3. ve 4. sınıflarından seçilen 338 öğrenciye uygulanmıştır. Araştırmanın sonuçlarına göre görsel matematik okuryazarlığı özyeterlik algısı ile problem çözme beceri algısı arasında düşük düzeyde, pozitif yönlü ve anlamlı bir ilişki vardır. Problem çözme beceri algısı ile görsel matematik okuryazarlığı özyeterlik algısının birbirini açıklama oranı yaklaşık \%9'dur. Öğrencilerin görsel matematik okuryazarlığı özyeterlik algıları cinsiyete göre kızlar lehine anlamlı bir farklılık göstermiştir. Diğer yandan öğrencilerin problem çözme beceri algıları cinsiyete göre anlamlı bir farklılık göstermemiştir.
\end{abstract}

Anahtar kelimeler: Görsel matematik okuryazarlığı özyeterlik algısı, problem çözme beceri algısı, ortaokul öğrencileri

\section{Giriş}

Matematik Öğretmenleri Ulusal Konseyi (NCTM) tarafindan matematiğin temel standartları arasında gösterilen problem çözme, öğrencilerin ortaokul düzeyinde öğrenim görmeye başladıkları dönemde karşılarına çıkan önemli bir kavramdır (Billstein, Libeskind, \& Johnny, 2004; Reusser \& Stebler, 1997; Schmidt \& Bednarz, 1997; Türnüklü \& Yeşildere, 2005). Problem çözme kavramının temelleri incelendiğinde bu kavramı ilk olarak okullarda Amerikalı filozof John Dewey kullanmıştır (Prawat, 2000). Dewey'e göre öğrenciler eğitim ortamlarında zihinsel ve fiziksel bakımdan uğraşı gerektiren birtakım problemlerle yüzleştirilmelidir (Philips \& Soltis, 2004). Bu nedenle bireyler problem çözmede tecrübelerinden, ön bilgilerinden ve çözüme ilişkin yöntemlerden yararlanmalıdır (Alcı, 2007; Korkut, 2002; Yalçın, Tetik, \& Açıkgöz, 2010).

Problem çözme sürecinin planlı olması bakımından Polya (1945) dört aşamadan oluşan problem çözme basamaklarını önermiştir. Bu basamaklar sırasıyla problem anlama, çözüme yönelik plan yapma, planı uygulama ve değerlendirme olarak isimlendirilmiştir. Üst düzey zihinsel etkinliklerin kazanılmasında kullanılan problem çözme (Otacıŏglu, 2008) aynı zamanda duyuşsal ve davranışsal işlemleri de içeren bir süreçtir (Heppner \& Petersen, 1982; aktaran, Biber \& Kutluca, 2013). Matematik literatüründe ise problem çözme, birtakım işlemler eşliğinde akıl yürütme süreçleri çalıştırılarak ve gerekli bilgiler kullanılarak sorunun ortadan kaldırılması şeklinde

\footnotetext{
* Bu makalenin bir bölümü XI. Ulusal Fen Bilimleri ve Matematik Eğitimi Kongresi bildiri kitabında kısa özet şeklinde yayınlanmıştır (Çukurova Üniversitesi, 11-14 Eylül 2014, Adana, Türkiye).

*** Sorumlu Yazar: Araştırma Görevlisi, Atatürk Üniversitesi, Erzurum, Türkiye, furkanozdemir24@ gmail.com

*** Öğretmen, Suluova Atatürk Ortaokulu, Amasya, Türkiye, denizyildizi2805@hotmail.com

**** Prof. Dr., Atatürk Üniversitesi, Erzurum, Türkiye, akaplan@ atauni.edu.tr
} 
tanımlanır (Altun, 1995; D’Zurilla \& Goldfried, 1971). Öğrenciler problem çözmeyi matematiksel ifadeleri anlayarak birbiriyle ilişkilendirmek, matematiksel içerikleri modellemek, matematiğin anlamlı olarak kullanımı noktasında güven tazelemek için kullanırlar (NCTM, 1989; Swings \& Peterson, 1988). Bireylerin günlük hayatta karşılarına çıkan problemlere çözüm üretebilmesi için uygun problem çözme becerilerine sahip olmaları gerekir (Berkant \& Eren, 2013; Taylan, 1990).

Matematik öğretiminin temel amaçları arasında yer alan (Verschaffel, De Corte, Lasure, Van Vaerenbergh, Bogaerts, \& Ratinckx, 1999) problem çözme becerisi, bireyin öğrenme amacını bilmesine rağmen ona nasıl ulaşacağını bilmediğinde sergilenen davranışlardır (Düzakın, 2004). Öğrenilebilen beceriler olarak bilinen problem çözme becerisi, bireyin çevresine uyum sağlamasına yardımcı olmaktadır (Bağçeci \& Kinay, 2013; Conger, Reuter, \& Elder, 1999). Bireylerin problem çözme becerilerine yönelik kendilerini nasıl algıladıkları da problem çözme sürecindeki davranışları etkilemektedir (Piersel, Larson, Allen, \& Imao, 1993). Bir bireyin problem çözme sürecindeki performansına yönelik inancı ya da yargısı problem çözme beceri algısı şeklinde tanımlanmıştır (Kaplan, Duran, \& Baş, 2016). Buna göre problem çözme beceri algısının problem çözme becerisini tetiklediği ya da problem çözme sürecindeki becerilerin problem çözme beceri algısına göre şekillendiği (Heppner, Witty, \& Dixon, 2004) ifade edilebilir.

Algılanan problem çözme becerisi Heppner ve Petersen (1982) tarafindan "problem çözme yeteneğine olan güven, yaklaşma-kaçınma ve kişisel kontrol” olmak üzere üç alt faktörle açıklanmıştır. Bu faktörlerden problem çözme yeteneğine olan güven faktörü, bireyin bir problemle karşılaştığında etkin çözüm yolu bulacağına yönelik inancıyla ilgilidir (Şahin, Şahin, \& Heppner, 1993). Yaklaşma-kaçınma faktörü, bireyin değişik problem çözme etkinliklerine yönelik yakın ve uzak durma eğilimiyle ilgilidir (Heppner \& Baker, 1997). Kişisel kontrol faktörü ise bireyin problem çözme sürecinde duygu ve davranışlarını kontrol edebilme inancı şeklinde açıklanır (Heppner \& Wang, 2003). Tüm bu boyutlar bireylerin gerçek yaşamdaki problem çözme becerilerine yönelik algılarını gösterdiği gibi onların farklı problem çözme becerilerine sahip olduğuna da dikkati çeker (Heppner ve diğerleri, 2004).

Serin, Bulut Serin ve Sayg1lı (2010)'a göre problem çözme becerisine inanan öğrenciler inanmayanlara oranla problem çözmeye daha fazla vakit ayırmakta ve göreve uygun farklı düşünceler geliştirmektedir. Ayrıca problem çözme becerilerini yüksek olarak algılayan bireylerin yüksek özgüven duygusuna sahip oldukları, karşılaştıkları olaylar karşısında fazla kaygılanmadıkları ve problemin çözümüne yönelik daha dikkatli davrandıkları görülmüştür (Heppner, Stephen, Stroizer \& Heppner, 1991; Rosenberg, 1989). Ancak günümüz dünyasında matematiksel problemlerin çözümünün sadece bireylerin kendilerine güvenmeleriyle ilgili olmadığı aynı zamanda probleme yönelik matematiksel dilin iyi anlaşılmasıyla da ilişkili olduğu bilinmektedir (Akkaya \& Memnun, 2012). Matematiksel dile hâkim olmanın iyi düzeyde matematik okuryazarlığını gerektirdiği düşünülmektedir (Akkaya \& Memnun, 2012; Çolak, 2006; MEB, 2008). Aynı durumun görsel matematik okuryazarlığı ile paralellik gösterdiği 
söylenebilir çünkü eğitimde anlamlı öğrenmeleri sağlamak için farklı disiplinler arasındaki entegrasyonlar söz konusudur (Çalık \& Çapa Aydın, 2014; Taşkın Can, Cantürk, \& Öngel, 2005). Modelleme sürecine benzer olarak problem çözme sürecinde öğrenciler verilen bir problemi önce anlamaya çalışmakta daha sonra zihinlerinde problemin çözümüne yönelik bir model tasarlamakta sonrada bu modeli kâğıda aktararak probleme görsel bir nitelik kazandırmaktadır (Baran, Topan, Bozkuş, \& Gündüz, 2013; Kaiser \& Willander, 2005).

Literatürde görsel matematik okuryazarlığı gündelik problemlerin görsel, tersine görüntüsel bilgilerin de matematiksel olarak değerlendirilmesi şeklinde tanımlanmıştır (Bekdemir \& Duran, 2012). Günlük hayatta ve matematik eğitiminde vazgeçilmez bir konuma sahip olan görsel matematik okuryazarlığı sayesinde görsel nesneler arasındaki matematiksel ilişkiler daha kolay anlaşılır (Tutkun, Erdoğan, \& Öztürk, 2014). Nitekim öğrencilerin geometrik cisim ve şekilleri etkileşimli bir biçimde çizme, görme ve analiz etmelerini amaçlayan (Bingölbali, 2013) Geogebra, Sketchpad ve Geospace gibi dinamik geometri yazılımları ile limit, türev, integral ve seri konularına ilişkin matematiksel ifadelerin görselleştirilmesini sağlayan (Baki, 2002; Hohenwarter \& Fuchs, 2004; Small \& Hosack, 1986) Derive, Mathematica, Matlab ve Converge gibi hesap yazılımları da günümüzde yoğun şekilde kullanılmaktadır. Görsel matematik okuryazarlığının gelişimine yönelik yapılan görselleştirme faaliyetleri, öğrencilerin başarılarını artırdığı gibi derse yönelik ilgi, motivasyon ve katılımı da olumlu etkiler (Draper, 2010; Goldenberg \& Couco, 1998; aktaran, Zengin \& Kutluca, 2011; Saha, Ayub \& Tarmizi, 2010). Görsel matematik okuryazarlığına vurgu yapan Zimmermann (1991) bir analiz dersinin başarılı olarak nitelendirilmesi ve kavramsal olarak anlaşılabilmesi için konunun görsellik boyutunun düşünülmesi gerektiğini belirtmiştir.

İktisadi İşbirliği ve Kalkınma Teşkilatı'nın (OECD) yürüttüğü Uluslararası Öğrenci Değerlendirme Projesi (PISA) matematik okuryazarlığ̣ alanında öğrencilerin; görsellerle ilgili matematiksel kavramları içeren günlük hayat problemlerine yönelik çözümleri ile ilgilenmektedir (İskenderoğlu \& Baki, 2011; MEB, 2008; OECD, 2007). Bunun yanı sıra görsel matematik okuryazarlığıyla ilgili olarak Amerika Birleşik Devletleri ve İsrail gibi ülkelerde teknoloji destekli yazılım programları üretilmekte ve bilgisayar tabanlı ortaokul programları geliştirilmektedir (Duran \& Bekdemir, 2013). Diğer yandan Avrupa Birliği'nin katkılarıyla finanse edilen ve sekiz avrupa üniversitesini kapsayan TEMPUS projesinde matematik dersine yönelik kullanılan alet sisteminin görsel anlamda modernizasyonu amaçlanmıştır. $\mathrm{Bu}$ sayede yaz okulu faaliyetleri şeklinde dördüncüsü Sırbistan'da gerçekleşen görsel matematik projesinde uzmanlar, matematik öğretmenleri ve öğrenciler görsel matematik okuryazarlı̆̆ düzeylerinin gelişimine yönelik atölyelerdeki deneyim merkezli matematik eğitimi uygulamalarına katılmış ve uygulama sürecindeki eğitim tekniklerini konferanslarda tartı̧̧mıştır (Feynvesi, Budinski, \& Lavicza, 2014).

Okuryazarlıklar hususunda bireylerin ilgi, istek, motivasyon, başarı ve davranışlarını etkileyen değişkenlerden birisi de özyeterliktir (Bandura, 1986; Schulz, 2005). Bireyin karşılaştığı bir problemin çözümü noktasında ne kadar başarılı 
olabileceğine yönelik inancı olan özyeterlik (Saunders, 2000; aktaran, Yeşilyaprak, 2002) aynı zamanda algılanan özyeterlik olarak tanımlanır (Senemoğlu, 2009). Günlük hayatta karşılaşılan sorunların üstesinden gelmede, sağlıklı bir yaşam sürdürmede ve sosyal başarının arttırılmasında bireylere pozitif yönde etki eden özyeterlik algısı, problem çözme sürecinin temel unsurları arasında kabul edilir ve üç boyuttan oluşur (Bandura, 1977, 1997; Mayer \& Wittrock, 1996; Sugrue, 1995). Bu boyutlar; bireyin performans gösterme kapasitesine yönelik inanc1, bireyin farklı düzeylerde bulunan yeterlik inancını başka durumlara genelleyebilmesi ve bireylerin problemler karşısında davranış sergileme inançlarındaki kararlılıktır (Maddux, 1995).

Özyeterlik algısı yüksek olan öğrenciler, algı düzeyi düşük olan öğrencilere göre problem çözme becerilerini öğrenmeye ve geliştirmeye daha yatkındır (Alcı, Erden, \& Baykal, 2010; Bouffard-Bouchard, Parent, \& Larivee, 1991; Gülten, 2013; Mayer, 1998). Bunun tam tersine özyeterlik algısı düşük olan öğrenciler ise düşük motivasyona sahip olurlar ve herhangi bir zorlukla karşılaştıklarında sorunun çözümüne yönelik karamsar yaklaşırlar (Bandura, 1994). $\mathrm{Bu}$ nedenle hem Amerika Birleşik Devletleri’ndeki Matematik Öğretmenleri Ulusal Konseyi (NCTM) hem de Milli Eğitim Bakanlığ1 (MEB) ortaokul matematik öğretiminde öğrencilerin problem çözme yeteneklerine yönelik özyeterlik algılarının geliştirilmesini önermiştir (MEB, 2005; NCTM, 2000). Öte yandan, Uluslararası Öğrenci Değerlendirme Projesi (PISA) ülkeler arasında matematik okuryazarlıklarını ve rutin olmayan problem çözme becerilerini belirli aralıklarla incelemiştir. PISA 2012 çalışmasında ülkemiz öğrencilerinin yaratıcı problem çözme becerisine yeterince sahip olmadıkları ve genel ortalamanın altında kaldıkları görülmüştür (İstanbul Aydın Üniversitesi, 2014). Buna göre ülkemiz öğrencileri temel matematiksel yeterlikler dışında üst düzey matematiksel problemleri çözmede yeterli beceriye sahip değildir. Matematik eğitiminde ortaokul öğrencilerine yönelik gerekli önlemlerin önceden alınması noktasında bireylerin hem problem çözme becerilerine hem de görsel matematik okuryazarlıklarına yönelik algılarının yakından incelenmesi gerekmektedir çünkü bireylerin problem çözme becerilerinde rol oynayan faktörler incelendiğinde bunlardan birisi de bireyin kendi algısıdır (Alc1, 2007). Matematik derslerinde problem çözme konusunda olumlu düşünen ve kendileriyle barışık olan bireylerin günlük hayatta başarılı oldukları unutulmamalıdır.

Literatür incelendiğinde problem çözme beceri algısıyla özyeterlik algıs1 kavramları arasındaki ilişkiyi inceleyen az sayıda çalışma tespit edilmiştir (Alcı ve diğerleri, 2010; Ançel, Erkal İlhan, \& Bıyıklı Gençtürk, 2015; Aylar \& Aksin, 2011; Aurah, Cassady, \& McConnell, 2014). Bu çalışmalardan elde edilen ortak sonuçlara göre öğretmen adaylarının özyeterlik algılarıyla problem çözme beceri algıları arasında pozitif yönde, anlamlı ilişki bulunmuştur. Aynı zamanda özyeterlik algısının problem çözme beceri algısını anlamlı şekilde yordadığı sonucuna ulaşılmıştır. Araştırmalardaki diğer ortak yanlar ise çalışmaların çoğunlukla matematik dersi dışında genel özyeterlik algısını incelemiş olması ve üniversite öğrencileriyle yürütülmüş olmasıdır. Özyeterlik algısını görsel matematik okuryazarlığı çerçevesinde değerlendiren çalışmaların sayısının oldukça sınırlı olduğu görülmektedir. Alanyazındaki çalışmalardan farklı 
olarak bu araştırmada özyeterlik algısı ile problem çözme beceri algısı arasındaki ilişki matematik dersi kapsamında ele alınarak değerlendirilmiştir. Ortaokul öğrencileri düzeyinde gerçekleştirilen bu çalışmada görsel matematik okuryazarlığı özyeterlik algısı ile genel anlamdaki problem çözme beceri algıları belirlenmiştir. Bu bakımdan mevcut çalışma alanyazındaki diğer çalışmalardan ayrılmaktadır. Bu araştırmadan elde edilecek sonuçların görsel matematik okuryazarlığı özyeterlik algısı ile problem çözme beceri algısı düşük düzeyde olan öğrencilere yönelik alınacak tedbirlerin belirlenmesi bakımından önemli olduğu düşünülmektedir.

\section{Araştırmanın Amacı}

$\mathrm{Bu}$ araştırmanın amacı ortaokul öğrencilerinin görsel matematik okuryazarlığ1 özyeterlik algıları ile problem çözme beceri algıları arasındaki ilişkinin olup olmadığını belirlemektir. Araştırmanın genel amacına uygun olarak aşağıdaki alt problemlere cevap aranmıştır:

1. Ortaokul öğrencilerinin problem çözme beceri algıları hangi düzeydedir?

2. Ortaokul öğrencilerinin görsel matematik okuryazarlığı özyeterlik algıları hangi düzeydedir?

3. Ortaokul öğrencilerinin görsel matematik okuryazarlı̆̆ı özyeterlik algıları ile problem çözme beceri algıları cinsiyetlerine göre anlamlı bir farklılık göstermekte midir?

4. Ortaokul öğrencilerinin görsel matematik okuryazarlığı özyeterlik algıları ile problem çözme beceri algılarının düzeyleri arasında anlamlı bir ilişki var midir?

5. Problem çözme beceri algısı görsel matematik okuryazarlığı özyeterlik algısının anlamlı bir yordayıcısı midır?

\section{Yöntem}

\section{Araştırma Modeli}

Nicel araştırma yaklaşımının benimsendiği bu çalışmada tarama modeli esas alınmıştır çünkü tarama modelinde, çok sayıda elemandan oluşan bir evrende, evren hakkında genel bir yargıya varmak için evrenin tümü ya da ondan alınacak bir grup, örnek ya da örneklem üzerinde tarama yapılmaktadır (Karasar, 2008).

\section{Araștırma Grubu}

Araştırma grubunu, 2013-2014 öğretim y1lı birinci döneminde Kars ilinden bir ve Erzurum ilinden iki olmak üzere üç devlet okulunun ortaokul üçüncü ve dördüncü sınıflarından seçilen $183 \mathrm{kız}$ ve 155 erkek toplam 338 öğrenci oluşturmuştur. Araştırmanın örneklemi uygun örnekleme yöntemi kullanılarak seçilmiştir çünkü uygun örnekleme yöntemi zaman, para, iş gücü açısından var olan sınırlılıklar nedeniyle örneklemin kolay ulaşılabilir ve uygulama yapılabilir birimlerden seçilmesidir (Büyüköztürk, Kılıç-Çakmak, Akgün, Karadeniz, \& Demirel, 2011). 


\section{Veri Toplama Araçları}

Araştırmanın veri toplama araçları Bekdemir ve Duran (2012) tarafindan geliştirilen "Görsel Matematik Okuryazarlığı Özyeterlik Algı Ölçeği” ile Serin ve diğerleri (2010) tarafindan geliştirilen "Çocuklar İçin Problem Çözme Envanteri” dir. "Görsel Matematik Okuryazarlığı Özyeterlik Alg1 Ölçeği” 5'li Likert tipinde olup 38 maddeden oluşmaktadır. Ölçek, "her zaman”, "sık sık", "bazen”, "nadiren” ve "hiçbir zaman” olarak derecelendirilmiştir. Ölçeğin Cronbach-Alpha güvenirlik katsayısı .96 olarak hesaplanmış, bu çalışmada ise Cronbach-Alpha güvenirlik katsayısı .93 olarak tespit edilmiştir.

“Çocuklar İçin Problem Çözme Envanteri” 5'li Likert tipinde olup 24 maddeden oluşmaktadır. Ayrıca, bu envanter üç alt faktörden oluşmaktadır. Bu alt faktörler: problem çözme becerisine güven, öz denetim ve kaçınma olarak adlandırılmıştır. Problem çözme becerisine güven, problemler karşısında kendine güveni, vazgeçmemeyi, kararlılığı ifade etmektedir. Öz denetim, problem karşısında kendini yönetebilme, daha özerk davranışlar, düşünceler geliştirebilme, iç denetimli özelliklerin baskınlığı ile ilgili ifadeler içermektedir. Kaçınma ise bir problemle karşılaşıldığında sorunu çözmek yerine erteleme, yoksayma, yüzleşememe, gerçek sorundan uzaklaşma eğiliminin ağır basması ile ilgili anlamlar içermektedir. Ölçek, "hiçbir zaman”, "ender olarak", "arada sırada", "sık sık" ve "her zaman" olarak derecelendirilmiştir. Ölçeğin Cronbach-Alpha güvenirlik katsayısı .80 olarak hesaplanmış, bu çalışmada ise Cronbach-Alpha güvenirlik katsayısı .79 olarak tespit edilmiştir.

\section{Verilerin Analizi}

Verilerin analizinde iki farklı istatistik analiz yöntemi kullanılmıştır. Bunlar betimsel ve kestirimsel olmak üzere öğrencilerin görsel matematik okuryazarlığ 1 özyeterlik algıları ile problem çözme beceri algılarının düzeyini belirlemek amacıyla ölçeklerden elde edilen puanların analizinde betimsel istatistik yönteminden yararlanılmıştır. Öğrencilerin özyeterlik ve beceri algılarına yönelik düzeyleri değerlendirilirken "dizi genişliği/yapılacak grup sayısı" (Tekin, 2009) formülüne göre aritmetik ortalama aralıkları belirlenmiştir.

Değerlendirmede kullanılan aritmetik ortalama aralıkları; "1.00-1.80=Asla, Hiçbir zaman", "1.81-2.60=Nadiren, Ender olarak", "2.61-3.40= Bazen", "3.41$4.20=$ S1k s1k, Çoğu zaman” ve "4.21-5.00= Her zaman” şeklindedir. Ölçeklerdeki puanlar 1 ile 5 arasında olduğundan, puanların 5.00'e yaklaştıkça öğrencilerin söz konusu görüşe katılım düzeylerinin yüksek, 1.00'e yaklaştığında ise düşük olduğu düşünülmüştür. Öğrencilerin görsel matematik okuryazarlığ1 özyeterlik alg1 ölçeğinden alabilecekleri en düşük puan 38, en yüksek puan ise 190 olarak belirlenmiştir. Öte yandan öğrencilerin problem çözme envanterinden alabilecekleri en düşük puan 24 , en yüksek puan ise 120 olarak belirlenmiştir.

Her iki ölçekteki alt boyutlar da betimsel istatistiklerle belirlenmiştir. Ölçeklerde yer alan maddelerin ortalamaları ve standart sapmaları hesaplandıktan sonra cinsiyet değişkenine göre farklılaşma durumuna bakılmıştır. Öğrencilerin görsel matematik okuryazarlığı özyeterlik algıları ile problem çözme beceri algılarının cinsiyet faktörüne 
göre farklılaşma durumunu belirlemek amaciyla kestirimsel istatistik yönteminden yararlanılmıştır. Buna göre öğrencilerin özyeterlik ve beceri algılarının cinsiyetlere göre farklılık gösterip göstermediğinin tespitinde bağımsız örneklem $t$ testi kullanılmıştır. Öğrencilerin görsel matematik okuryazarlığı özyeterlik algıları ile problem çözme beceri algılarının düzeyleri arasında anlamlı bir ilişkinin olup olmadığını belirlemede Pearson Momentler Korelasyon analizinden yararlanılmıştır. Elde edilen bu ilişki için, problem çözme beceri algısının görsel matematik okuryazarlığı özyeterlik algısının anlamlı bir yordayıcısı olup olmadığının tespitinde basit doğrusal regresyon analizi kullanılmıştır.

\section{Bulgular}

$\mathrm{Bu}$ bölümde çalışmada ele alınan soruların yanıtlarına yönelik toplanan verilere uygulanan analizlere, yapılan analizler sonucunda elde edilen bulgulara ilişkin ulaşılan sonuçlara ve yorumlara yer verilmiştir.

\section{Araştırmanın Birinci ve İkinci Alt Problemlerinden Elde Edilen Bulgular}

Ortaokul öğrencilerinin görsel matematik okuryazarlığı özyeterlik algıları ile problem çözme beceri algılarının düzeyini belirlemek amacıyla ölçeklerden elde edilen puanlara ait aritmetik ortalama ve standart sapma değerlerinden yararlanılmıştır. Öğrencilerin ölçeklerden ve alt ölçeklerden elde ettikleri puanlara ilişkin aritmetik ortalama ve standart sapma değerleri Tablo 1'de sunulmuştur.

Tablo 1

Öğrencilerin Ölçeklerden Elde Ettikleri Puanlara Ait Aritmetik Ortalama ve Standart Sapma Değerleri

\begin{tabular}{lcccc}
\hline & $n$ & $\overline{\mathrm{x}}$ & ss & Katılma Düzeyi \\
\hline $\begin{array}{l}\text { Problem Çözme } \\
\text { Beceri Algısı }\end{array}$ & 338 & 3.49 & .33 & Sık Sık \\
\hline $\begin{array}{l}\text { Problem Çözme } \\
\text { Becerisine Güven }\end{array}$ & 338 & 3.67 & .37 & Sık Sık \\
\hline Öz Denetim & 338 & 3.04 & .47 & Bazen \\
\hline Kaçınma & 338 & 3.72 & .49 & Sık Sık \\
\hline $\begin{array}{l}\text { Görsel Matematik } \\
\begin{array}{l}\text { Okuryazarlı } \\
\text { Algısı }\end{array}\end{array}$ & 338 & 3.69 & .34 & Sık Sık \\
\hline
\end{tabular}

Tablo 1 incelendiğinde, öğrencilerin problem çözme beceri algılarının "sık s1k" düzeyinde olduğu tespit edilmiştir. Yani öğrenciler orta düzeyin üzerinde bir problem çözme beceri algısına sahiptirler. Alt ölçeklerdeki görüşler incelendiğinde ise, öğrencilerin Problem Çözme Becerisine Güven ve Kaçınma alt ölçeğinde "sık sık" 
düzeyinde, Öz Denetim alt ölçeğinde ise "bazen" düzeyinde olduğu tespit edilmiştir. Bu bulgulara göre öğrencilerin algıları Problem Çözme Becerisine Güven ve Kaçınma alt ölçeklerinde orta düzeyin üzerinde iken Öz Denetim alt ölçeğinde orta düzeyde olduğu görülmektedir. Öğrencilerin görsel matematik okuryazarlığı özyeterlik algılarına ait verilere bakıldığında ise, öğrencilerin görsel matematik okuryazarlığı özyeterlik algılarının "sık sık" düzeyinde olduğu belirlenmiştir. Yani öğrencilerin görsel matematik okuryazarlığı özyeterlik algılarının orta düzeyin üzerinde olduğu söylenebilir.

\section{Araştırmanın Üçüncü Alt Probleminden Elde Edilen Bulgular}

Ortaokul öğrencilerinin görsel matematik okuryazarlığı özyeterlik algıları ile problem çözme beceri algılarının cinsiyetlerine göre değişip değişmediğinin belirlenmesi için ölçeklerden elde edilen puan ortalamalarına bağımsız örneklem $t$ testi uygulanmıştır. Bağımsız örneklem $t$ testinin uygulanmasıyla elde edilen verilere Tablo 2'de yer verilmiştir.

Tablo 2

Öğrencilerin Cinsiyetlerine Göre Ölçeklerden ve Alt Ölçeklerden Elde Ettikleri Puanlara Uygulanan Bă̆ımsız Örneklem T Testi Sonuçları

\begin{tabular}{|c|c|c|c|c|c|c|}
\hline & Cinsiyet & $n$ & $\overline{\mathrm{x}}$ & ss & $t$ & $p$ \\
\hline Problem & Erkek & 155 & 3.62 & .36 & \multirow[b]{2}{*}{1.131} & \multirow[b]{2}{*}{.259} \\
\hline $\begin{array}{l}\text { Çözme } \\
\text { Becerisine } \\
\text { Güven }\end{array}$ & $\mathrm{K} 1 \mathrm{z}$ & 183 & 3.70 & .27 & & \\
\hline \multirow[t]{2}{*}{ Öz Denetim } & Erkek & 155 & 3.09 & .37 & \multirow{2}{*}{-.983} & \multirow{2}{*}{.326} \\
\hline & Kız & 183 & 3.00 & .37 & & \\
\hline \multirow[t]{2}{*}{ Kaçınma } & Erkek & 155 & 3.55 & .51 & \multirow{2}{*}{3.519} & \multirow{2}{*}{.000} \\
\hline & $\mathrm{K} 1 \mathrm{z}$ & 183 & 3.87 & .40 & & \\
\hline Problem & Erkek & 155 & 3.45 & .53 & \multirow[b]{2}{*}{1.402} & \multirow[b]{2}{*}{.162} \\
\hline $\begin{array}{l}\text { Çözme } \\
\text { Beceri } \\
\text { Algisı }\end{array}$ & $\mathrm{K} 1 \mathrm{z}$ & 183 & 3.53 & .42 & & \\
\hline Görsel & Erkek & 155 & 3.61 & .36 & \multirow[b]{2}{*}{1.986} & \multirow[b]{2}{*}{.048} \\
\hline $\begin{array}{l}\text { Matematik } \\
\text { Okuryazarlık } \\
\text { Algisı }\end{array}$ & $\mathrm{K} ı \mathrm{z}$ & 183 & 3.75 & .31 & & \\
\hline
\end{tabular}

Tablo 2 göz önüne alındığında, öğrencilerin görsel matematik okuryazarlığ1 özyeterlik algıları cinsiyete göre kız öğrenciler lehine anlamlı farklılık göstermiştir $(\mathrm{p}<.05)$. Diğer yandan öğrencilerin problem çözme beceri algıları cinsiyete göre incelendiğinde kız öğrenciler lehine bir farklılık görülse de bu fark istatistiksel olarak 
anlamlı değildir ( $\mathrm{p}>.05)$. Problem çözme envanterinin alt ölçekleri incelendiğinde ise problem becerisine güven alt boyutunda kızlar, öz denetim alt ölçeğinde erkek öğrenciler lehine bir fark vardır. Fakat bu farklar istatistiksel olarak anlamlı değildir ( $>$ >.05). Kaçınma alt ölçeğinde ise kız öğrenciler lehine anlamlı bir farklılık görülmüştür $(\mathrm{p}<.05)$.

\section{Araștırmanın Dördüncü ve Beşinci Alt Probleminden Elde Edilen Bulgular}

Öğrencilerin görsel matematik okuryazarlığı özyeterlik algıları ile problem çözme beceri algılarının düzeyleri arasında anlamlı bir ilişkinin olup olmadığını ve eğer varsa bu ilişkinin yönünü ve şiddetini tespit etmek için basit korelasyon analizi kullanılmıştır. Analiz sonucunda elde edilen veriler Tablo 3 'te sunulmuştur.

Tablo 3

Öğrencilerin Görsel Matematik Okuryazarlık Algısı ile Problem Çözme Beceri Algıları Arasındaki İlişkinin Tespiti İçin Uygulanan Basit Korelasyon Analizi

\begin{tabular}{lccccc}
\hline & $\begin{array}{c}\text { Problem } \\
\text { Çözme Beceri } \\
\text { Algıs }\end{array}$ & $\begin{array}{c}\text { Problem } \\
\text { Çözme } \\
\text { Becerisine } \\
\text { Güven }\end{array}$ & Öz Denetim & Kaçınma \\
\hline Görsel & $\mathrm{r}$ & $.296^{* *}$ & $.420^{* *}$ & .015 & .063 \\
Matematik & $\mathrm{p}$ & .000 & .000 & .784 & .245 \\
Okuryazarlık & $\mathrm{N}$ & 338 & 338 & 338 & 338 \\
Algis1 & & & & &
\end{tabular}

Tablo 3'teki veriler incelendiğinde, öğrencilerin görsel matematik okuryazarlığ1 özyeterlik algıları ile problem çözme beceri algılarının düzeyleri arasında pozitif yönde ve düşük düzeyde anlamlı bir ilişkinin olduğu görülmüştür $(r=.296, p<.01)$. Ayrıca, öğrencilerin problem çözme beceri algıları ile görsel matematik okuryazarlığı özyeterlik algısının birbirini açıklama oranı yaklaşık \% 9'dur $\left(\mathrm{R}^{2}=.088\right)$.

Problem çözme envanterinin alt ölçeklerinden elde edilen alg1 puanları ile öğrencilerin görsel matematik okuryazarlığı özyeterlik algıları arasındaki ilişki incelendiğinde, öğrencilerin görsel matematik okuryazarlığ özyeterlik algıları ile Öz Denetim ve Kaçınma alt boyutları arasında anlamlı bir ilişki yokken, Problem Çözme Becerisine Güven alt boyutu arasında pozitif yönlü ve orta düzeyde anlamlı bir ilişki tespit edilmiştir $(\mathrm{r}=.520, \mathrm{p}<.01)$.

Öğrencilerin görsel matematik okuryazarlığı özyeterlik algılarının problem çözme beceri algılarının anlamlı bir yordayıcısı olup olmadığını tespit edebilmek amacıyla ilgili puanlara basit doğrusal regresyon analizi uygulanmıştır. Yapılan regresyon analizi sonuçlarına Tablo 4'te yer verilmiştir. 
Tablo 4

Görsel Matematik Okuryazarlı̆̆ Özyeterlik Algısı ile Problem Çözme Beceri Algısının Yordanmasına İlişkin Basit Doğrusal Regresyon Sonucu

\begin{tabular}{lccccc}
\hline Değişkenler & B & Standart hata & $\beta$ & $t$ & $p$ \\
\hline Sabit & 92.904 & 8.428 & & 11.023 & .000 \\
\hline $\begin{array}{l}\text { Problem Çözme Beceri } \\
\text { Algis1 }\end{array}$ & .564 & .099 & .296 & 5.682 & .000 \\
\hline$R=.30, R^{2}=.088, F(1,336)=32.29, p=.000$ & & & &
\end{tabular}

Tablo 4'e göre, problem çözme beceri algıs1 görsel matematik okuryazarlığ özyeterlik algısının anlamlı bir yordayıcısıdır $\left(\mathrm{R}=.30, \mathrm{R}^{2}=.088, \mathrm{~F}(1,336)=32.29\right.$, $\mathrm{p}=.000$ ). Buna göre, öğrencilerin görsel matematik okuryazarlığı özyeterlik algılarındaki varyansın \% 9'u öğrencilerin problem çözme beceri algıları ile açıklanabilir. Bu ilişkiye ait elde edilen matematiksel model ise, "Görsel Matematik Okuryazarlığı Özyeterlik Algısı $=92.904+0.564$ x Problem Çözme Beceri Algısı” şeklindedir.

\section{Sonuç ve Tartışma}

Ortaokul öğrencilerinin görsel matematik okuryazarlı̆̆ özyeterlik algılarını ve problem çözme beceri algılarını ortaya çıkarmayı ayrıca öğrencilerin görsel matematik okuryazarlığı özyeterlik algıları ile problem çözme beceri algılarının düzeyleri arasında anlamlı bir ilişkinin olup olmadığını tespit etmeyi amaçlayan bu çalışmada şu sonuçlar elde edilmiştir.

Araştırmanın birinci alt problemine yanıt bulmak için yapılan inceleme sonucunda, öğrencilerin problem çözme beceri algılarının yüksek düzey ile orta düzey arasında bir düzeyde olduğu tespit edilmiştir. Yani, öğrenciler ortalamanın üzerinde bir problem çözme beceri algısına sahiptirler. Çalışmaya katılan öğrencilerin problem çözme becerisi açısından kendilerini yeterli düzeyde algıladıkları söylenebilir. Elde edilen bu bulgu Serin ve diğerlerinin (2010) ilköğretim düzeyinde öğrenim gören öğrencilerin problem çözmede kendilerini yeterli buldukları görüşüyle uyumludur. Aynı bulgu, Yalçın ve diğerlerinin (2010) öğrencilerin kendilerini başarılı olarak algılamalarının problem çözme becerilerinde önemli bir etken olduğu şeklindeki görüşüyle tutarlıdır. Ortaokul öğrencilerinin problem çözme becerilerine yönelik algılarının yüksek ile orta düzey arasında olması onların problem çözme becerileriyle birlikte bu becerilere güven duymaları (Bingham, 1998; Gömleksiz \& Bozpolat, 2012) ve problem çözme etkinliklerine yakınlık hissetmeleriyle (Heppner \& Baker, 1997) açıklanabilir.

Araştırmanın ikinci alt problemine yanıt bulmak için yapılan inceleme sonucunda, öğrencilerin görsel matematik okuryazarlığı özyeterlik algılarının orta düzey ile yüksek düzey arasında bir düzeyde olduğu belirlenmiştir. Bu bulgulara dayanarak, öğrencilerin görsel matematik okuryazarlı̆̆ı öz yeterlik algılarının orta düzeyin üzerinde 
olduğu söylenebilir. Herhangi bir konuda özyeterlik algısı ile başarı arasında yakın ilişki olduğundan (Pajares, 2001; Senemoğlu, 2009) öğrencilerin görsel matematik okuryazarlığıyla ilgili özyeterlik algılarının orta düzeyin üzerinde olması öğrencilerin problem çözme beceri algılarının da aynı paralelde artabileceği şeklinde yorumlanabilir. Ortaokul öğrencilerinin görsel matematik okuryazarlığına yönelik özyeterlik algılarının yüksek ile orta düzey arasında olması onların temel matematiksel işlemlerde, matematiksel dili kullanarak ifadeleri matematiksel olarak yorumlamada ve gündelik matematiksel ilişkileri belirlemedeki yeterliklerine (Bekdemir \& Duran, 2012) yönelik olumlu tutumlarıyla açıklanabilir.

Araştırmanın üçüncü alt problem olan ortaokul öğrencilerinin görsel matematik okuryazarlığı özyeterlik algıları ile problem çözme beceri algılarının cinsiyete göre farklılaşıp farklılaşmadığının belirlenmesi adına yapılan analizler sonucunda öğrencilerin görsel matematik okuryazarlığı özyeterlik algıları cinsiyete göre kız öğrenciler lehine anlamlı farklılık göstermiştir. Ortaokul öğrencilerinin görsel matematik okuryazarlığına yönelik özyeterlik algılarının kız öğrenciler lehine anlamlı farklılık göstermesinin nedeni öğrencilerin kültürel durumlarından (Özgen \& Bindak, 2011) kaynaklanıyor olabilir. İlgili literatür incelendiğinde görsel matematik okuryazarlığı özyeterlik algısının kız öğrenciler lehine farklılaştığını ortaya koyan çalışmalar (Tutkun ve diğerleri, 2014) olduğu gibi, erkek öğrenciler lehine farklılaştığını gösteren araştırmalar da vardır (Özgen \& Bindak, 2011; Sarı Uzun, Yanık, \& Sezen, 2012). Hatta bazı çalışmalarda matematik okuryazarlığı özyeterlik algısının cinsiyet faktörüne göre farklılaşmadığı ortaya konulmuştur (Birgün \& Gülbez, 2014; Duran, 2011; Soytürk, 2011). Tüm bu sonuçlar incelendiğinde öğrencilerin görsel matematik okuryazarlığı özyeterlik algılarının cinsiyete göre farklılaşma durumu hakkında net bir sonucun ortaya koyulamadığ 1 söylenebilir.

Öğrencilerin problem çözme beceri algıları cinsiyete göre anlamlı bir farklılık göstermemiştir. Araştırmanın üçüncü alt probleminden elde edilen bu bulgu problem çözme konusunda cinsiyet değişkeninin problem çözme becerisine etkisi olmadığını belirten çalışmalarla (Çam, 1997; Güçray, 2003; Taylan, 1990; Terzi, 2003; Yıldırım \& Yalçın, 2008) paralellik göstermektedir. Problem çözme becerilerine yönelik algıların cinsiyete göre farklılaşma durumu bireylerin kaygı ve güven duyma durumlarıyla ilişkili olabileceği gibi, cinsiyet rolleriyle de (Sezen \& Paliç, 2011) ilgili olabilmektedir. Toplumların erkek ve bayan bireylere biçtiği sorumluluklar farklılaştı̆̆ 1 için karşılaşılan problemlerle başa çıkma dirençleri de değişiklik (Polat \& Tümkaya, 2010) gösterebilmektedir. Farklı kültürlere sahip bireylerin karşılaştıkları problem türlerinin ve iç dünyalarını etkileyen diğer etmenlerin birbirinden farklı olduğu düşünüldüğünde cinsiyet faktörünün erkek ya da bayan bireyler lehine farklılaşma durumu söz konusu olabileceği gibi farklılaşmama durumları da ihtimal dahilinde değerlendirilmelidir.

Son olarak, araştırmanın dördüncü ve beşinci sorusuna yanıt bulmak için incelemeler yapılmıştır. Yapılan inceleme sonucunda, öğrencilerin görsel matematik okuryazarlığı özyeterlik algıları ile problem çözme beceri algılarının düzeyleri arasında düşük düzeyde, pozitif yönlü ve anlamlı bir ilişkinin olduğu görülmüştür. Ayrıca, 
öğrencilerin problem çözme beceri algı düzeyi ile görsel matematik okuryazarlığ 1 özyeterlik algısının birbirini açıklama oranı yaklaşı \% 9'dur. Ortaokul öğrencilerinin problem çözme beceri algılarının zayıf da olsa anlamlı olarak görsel matematik okuryazarlığı özyeterlik algılarını etkilediği söylenebilir. Ancak elde edilen bu sonuç görsel matematik okuryazarlığı özyeterlik algısı ile problem çözme beceri algısı arasındaki ilişkinin başka değişkenlerden de etkilendiğinin bir kanıtı olarak gösterilebilir. Bu nedenle görsel matematik okuryazarlığ 1 özyeterlik algısını problem çözme beceri algısı dışında etkileyen diğer değişkenlerin ortaya çıkarılması gerekir. Ortaya çıkan bu sonucun diğer bir nedeni ise algı gibi duyuşsal faktörlerin zamana ve bireye göre değişim göstermesi (Taşkın, Aydın, Akşan, \& Güven, 2012) olabilir. Bireylerin kendilerine yönelik güvenlerinin artması problem çözme becerilerinin gelişimine katkı sağlamaktadır (Bouffard ve diğerleri, 1992; Gömleksiz \& Bozpolat, 2012). Araştırmanın dördüncü ve beşinci alt problemlerinden elde edilen bulgular Sugrue (1995), Mayer ve Wittrock (1996) ile Glaser, Raghavan ve Baxter'in (1992) özyeterlik algısının problem çözme sürecinin önemli öğeleri olduğu görüşüyle benzerlik göstermiştir. Ayrıca araştırmanın bu alt problemlerine ait bulgular Aurah ve diğerleri (2014) ile Alcı ve diğerlerinin (2010) matematik özyeterlik algısı ile algılanan problem çözme becerisi arasında pozitif yönlü, zayıf düzeyde ve anlamlı bir ilişki olduğu görüşüyle paralellik göstermiştir.

\section{Öneriler}

Araştırmadan elde edilen bulgulara göre ortaokul ögrencilerinin problem çözme beceri alg1sı altındaki öz denetim faktöründe "bazen" düzeyinde bir algıya sahip oldukları tespit edilmiştir. Öz denetimin problemler karşısında kendini yönetebilme ve daha bağımsız davranışlar sergileyebilme olduğu göz önüne alınırsa bireylerin neden bu şekilde bir algıya sahip oldukları nitel yollarla daha derinlemesine araştırılarak söz konusu algının nedenini ortaya çıkarabilir. Ortaokul öğrencilerinin görsel matematik okuryazarlığı özyeterlik algılarının cinsiyete göre farklılaşıp farklılaşmadığını inceleyen araştırmalardan elde edilen bulgular değişkenlik göstermektedir. Buradan hareketle ortaya çıkan bu farklılıkların bireylerin bölgeler arasındaki kültürel farklılıklarından mı yoksa bilişsel farklılıklardan mı kaynaklandığı daha detaylı bir şekilde araştırılabilir. Benzer şekilde ortaokul öğrencilerinin problem çözme beceri algılarının cinsiyete göre farklılaşmama nedenleri araştırılabilir. İyi bir problem çözme beceri algısına sahip olmak görsel matematik okuryazarlığı özyeterlik algısını güçlü kılacağından bireylerin öğrenme sürecinde problem çözme beceri algılarını arttıracak etkinlikler düzenlenmelidir. Hatta bireylere rutin ve rutin olmayan problemleri çözebilme alışkanlıkları kazandırılmalıdır. 


\section{Kaynakça}

Akkaya, R., \& Memnun, D. (2012). Öğretmen adaylarının matematiksel okuryazarlığa ilişkin öz-yeterlik inançlarının çeşitli değişkenler açısından incelenmesi. Dicle Üniversitesi Ziya Gökalp Ĕ̈itim Fakültesi Dergisi, 19, 96-111.

Alc1, B. (2007). Yıldız teknik üniversitesi üniversite öğrencilerinin matematik başarıları ile algıladıkları problem çözme becerileri, özyeterlik algıları, bilişüstü özdüzenleme stratejileri ve öss sayısal puanları arasındaki açıklayıcı ve yordayıcı ilişkiler örüntüsü (Yayınlanmamış doktora tezi). Yıldız Teknik Üniversitesi, İstanbul.

Alcı, B., Erden, M., \& Baykal, A. (2010). Üniversite öğrencilerinin matematik başarıları ile algıladıkları problem çözme becerileri, özyeterlik algıları, bilişüstü özdüzenleme stratejileri ve öss sayısal puanları arasındaki açıklayıcı ve yordayıcı ilişkiler örüntüsü. Boğaziçi Üniversitesi Eğitim Dergisi, 25(2), 53-68.

Altun, M. (1995). İlkokul 3., 4. ve 5.sınıf öğrencilerinin problem çözme davranışları üzerine bir çalışma (Yayınlanmamış doktora tezi). Hacettepe Üniversitesi, Ankara.

Ançel, G., Erkal İlhan, S., \& Bıyıklı Gençtürk, Z. (2015). An analysis of the relationship between self-efficacy beliefs and perceived problem solving ability among nursing and midwifery students. Türkiye Klinikleri Journal of Nursing, 7(1), 20-28.

Aurah, C.M., Cassady, J.C., \& McConnell, T.J. (2014). Predicting problem solving ability from metacognition and self-efficacy beliefs on a cross validated sample. British Journal of Education, 2(1), 49-72.

Aylar, F., \& Aksin, A. (2011). Sosyal bilgiler öğretmen adaylarının öz-yeterlilik inanç düzeyleri ve problem çözme becerileri üzerine bir araştırma (Amasya örneği). Ahi Evran Üniversitesi Eğitim Fakültesi Dergisi, 12(3), 299-313.

Bağçeci, B., \& Kinay, İ. (2013). Öğretmenlerin problem çözme becerilerinin bazı değişkenlere göre incelenmesi. Elektronik Sosyal Bilimler Dergisi, 12(44), 335-347.

Baki, A. (2002). Öğrenen ve ögretmenler için bilgisayar destekli matematik. İstanbul: Ceren Yayın-Dağıtım.

Bandura, A. (1997). Self-efficacy: The exercise of control. New York: W.H. Freeman and Company.

Bandura, A. (1994). Self-efficacy. In V.S. Ramachaudran (Eds), Encyclopedia of human behavior (pp. 74-81). New York: Academic Press.

Bandura, A. (1986). Social foundations of thought and action: A social cognitive theory. New Jersey: Prentice Hall.

Bandura, A. (1977). Self-efficacy: Toward a unifying theory of behavioral change. Psychological Review, 84, 191-215.

Baran, T., Topan, B., Bozkuş, F., \& Gündüz, N. (2013). 8.sınıf öğrencilerinin görsel matematik okuryazarlı düzeyleri ile grafik okuma becerileri arasındaki ilişki. I. 
Türk Bilgisayar ve Matematik Eğitimi Sempozyumu'nda sunulmuş bildiri, Karadeniz Teknik Üniversitesi, Trabzon, Türkiye.

Bekdemir, M., \& Duran, M. (2012). İlköğretim öğrencileri için görsel matematik okuryazarlığı özyeterlik alg1 ölçeği (GMOYÖYAÖ)'nin geliştirilmesi. Ondokuz Mayıs Üniversitesi Eğitim Fakültesi Dergisi, 31(1), 89-115.

Berkant, H.G., \& Eren, İ. (2013). İlköğretim matematik öğretmenliği bölümü öğrencilerinin problem çözme becerilerinin bazı değişkenler açısından incelenmesi. The Journal of Academic Social Science Studies International Journal of Social Science, 6(3), 1021-1041.

Biber, A.Ç., \& Kutluca, A.Y. (2013). Farklı öğretim kademelerindeki öğrencilerin problem çözme becerisi algılarının çeşitli değişkenler açısından incelenmesi. Abant İzzet Baysal Üniversitesi Ë̆itim Fakültesi Dergisi, 13(2), 276-288.

Billstein, R., Libeskind, S., \&Johnny, W. (2004). A problem solving approach to mathematics for elementary school teachers. New York: Addison Wesley Longman.

Bingham, A. (1998). Çocuklarda problem çözme yeteneklerinin geliştirilmesi. (Çev: Ferhan Oğuzkan). İstanbul: MEB Yayınları.

Bingölbali, E. (2013). Türev kavramına ilişkin öğrenme zorlukları ve kavramsal anlama için öneriler. In M.F. Özmantar, E. Bingölbali \& H. Akkoç (Eds.), Matematiksel kavram yanılgıları ve çözüm önerileri (pp. 223-255). Ankara: Pegem Akademi.

Birgin, O., \& Gülbez, B. (2014). Ortaokul 6-8.sınıf ögrencilerinin görsel matematik okuryazarlık özyeterlik algllarının incelenmesi. 11. Ulusal Fen Bilimleri ve Matematik Eğitimi Kongresi’nde sunulmuş bildiri, Çukurova Üniversitesi, Adana, Türkiye.

Bouffard-Bouchard, T., Parent, S., \& Larivee, S. (1991). Influence of self-efficacy on self-regulation and performance among junior and senior high-school students. International Journal of Behavioral Development, 14, 153-164.

Büyüköztürk, Ş., Kılıç Çakmak, E., Akgün, Ö.E., Karadeniz, Ş., \& Demirel, F. (2011). Bilimsel araştırma yöntemleri. Ankara: Pegem Yayınları.

Conger, R.D., Reuter, M.A., \& Elder, G.H. (1999). Couple resilience to economic pressure. Journal of Personality and Social Psychology, 76, 54-71.

Çalık, B., \& Çapa Aydın, Y. (2014). Development of visual mathematics literacy selfefficacy scale for prospective teachers. Proceedings of EERA/ECER, Porto, Portugal.

Çam, S. (1997). Öğretmenlik formasyon eğitimi programının öğretmen adaylarının problem çözme beceri algılarına etkisi. Çukurova Üniversitesi Ĕ̆itim Fakültesi Dergisi, 15(2), 56-61. 
Çolak, S. (2006). Materyal kullanımının ilköğretim altıncı sınıf öğrencilerinin matematik dersindeki geometrik kavramlarla ilgili okuryazarlığına etkisi (Yayınlanmamış yüksek lisans tezi). Gazi Üniversitesi, Ankara.

Draper, D. (2010). Comprehension strategies: Visualising \& visual literacy. Northern Adelaide: DECS Curriculum Consultant.

Duran, M. (2011). İlköğretim 7.sınıf öğrencilerinin görsel matematik okuryazarlı̆̆ özyeterlik algıları ile görsel matematik başarıları arasındaki ilişki. (Yayınlanmamış yüksek lisans tezi). Erzincan Üniversitesi, Erzincan.

Duran, M., \& Bekdemir, M. (2013). Görsel matematik okuryazarlığı özyeterlik algısıyla görsel matematik başarısının değerlendirilmesi. Pegem Ĕ̆itim ve Ögrretim Dergisi, $3(3), 27-40$.

Düzakın, S. (2004). Lise öğrencilerinin problem çözme becerilerinin bazı değişkenler açısından incelenmesi (Yayınlanmamış yüksek lisans tezi). Gazi Üniversitesi, Ankara.

D'Zurilla, T.J., \& Goldfried, M.R. (1971). Problem solving and behaviour modification. Journal of Abnormal Psychology, 18, 407-426.

Feynvesi, K., Budinski, N., \& Lavicza, Z. (2014). Two solutions to an unsolvable problem: Connecting origami and geogebra in a serbian high school. In G. Greenfield, G. Hart, \& R. Sarhangi (Eds.), Proceedings of Bridges 2014: Mathematics, Music, Art, Architecture, Culture (pp. 95-102).

Glaser, R., Raghavan, K., \& Baxter, G.P. (1992). Cognitive theory as the basis for design of innovative assessment: Design characteristics of science assessment. Los Angeles: University of California, National Center for Research on Evaluation, Standards, and Student Testing.

Gömleksiz, M.N., \& Bozpolat, E. (2012). İlköğretim 4. ve 5. sınıf öğrencilerinin problem çözme becerilerine ilişkin görüşlerinin değerlendirilmesi. Abant İzzet Baysal Üniversitesi Eğitim Fakültesi Dergisi, 12(2).

Güçray, S.S. (2003). The analysis of decision making behaviors and perceived problem solving skills in adolescents. The Turkish Online Journal of Educational Technology-TOJET, 2(2), 29-37.

Gülten, D. (2013). İlköğretim matematik öğretmen adaylarının matematik okuryazarlık öz-yeterlik inançlarının çeşitli değişkenler açısından incelenmesi. International Journal of Educational Sciences, 5(2), 393-408.

Heppner, P.P., \& Baker, C.E. (1997). Application of problem solving inventory. Measurement and Evaluation in Counseling and Development, 29(4), 129-143.

Heppner, P.P., \& Petersen, C.H. (1982). The development of implications of a personal problem solving inventory. Journal of Counseling Psychology, 29, 66-75. 
Heppner, P.P., Stephen, W.C., Stroizer, A.L., \& Heppner, M.J. (1991). An investigation of coping styles and gender differences with farmers in career transition. Journal of Counseling Psychology, 38(2), 167-174.

Heppner, P.P., \& Wang, Y. (2003). Problem-solving appraisal. In S.J. Lopez \& C.R. Synder (Eds.), Positive psychology assessment: Handbook of models and measures (pp. 127-138). Washington, DC: American Psychological Association.

Heppner, P.P., Witty, T.E., \& Dixon, W.A. (2004). Problem solving appraisal: Helping normal people lead better lives. The Counseling Psychologist, 32(3), 466-472.

Hohenwarter, M., \& Fuchs, K. (2004). Combination of dynamic geometry, algebra and calculus in the software system GeoGebra. In Computer Algebra Systems and Dynamic Geometry Systems in Mathematics Teaching Conference. Pecs, Hungary.

İskenderoğlu, T., \& Baki, A. (2011). İlköğretim 8.sınıf matematik ders kitabındaki soruların PISA matematik yeterlik düzeylerine göre sinıflandırılması. Ĕgitim ve Bilim, 36(161), 287-301.

İstanbul Aydın Üniversitesi. (2014). PISA 2012 yaratıcı problem çözme sonuçları. Retrieved May 30, 2016 from the World Wide Web: http://egitimplatformu.aydin.edu.tr/gundem/haber_detay.asp?haberID=77

Kaiser, G., \& Willander, T. (2005). Development of mathematical literacy: Results of an empirical study. Teaching Mathematics and Its Applications, 24(2-3), 48-60.

Kaplan, A., Duran, M., \& Baş, G. (2016). Ortaokul öğrencilerinin matematiksel üstbiliş farkındalıkları ile problem çözme beceri algıları arasındaki ilişkinin yapısal eşitlik modeliyle incelenmesi. İnönü Üniversitesi Eğitim Fakültesi Dergisi, 17(1), 1-16.

Karasar, N. (2008). Bilimsel araştırma yöntemi (17. baskı). Ankara: Nobel Yayın Dağıtım.

Korkut, F. (2002). Lise öğrencilerinin problem çözme becerisi. Hacettepe Üniversitesi Eğitim Fakültesi Dergisi, 22, 177-184.

Maddux, J.E. (1995). Self-efficacy theory: An introduction. In J.E. Maddux (Ed.), Selfefficacy, adaptation, and adjustment: Theory, research and application (pp. 3-33). New York: Plenum.

Mayer, R.E. (1998). Cognitive, metacognitive and motivational aspects of problem solving. Instructional Science, 26, 49-63.

Mayer, R.E., \& Wittrock, M.C. (1996). Problem-solving transfer. In D.C. Berliner \& R.C. Calfee (Eds.), Handbook of educational psychology (pp. 47-62). New York: Macmillan.

Milli Eğitim Bakanlığı. (2008). PISA'da okuma becerileri: PISA'da matematik okuryazarlı̆̆l. Retrieved April 26, 2014 from the World Wide Web: http://egitek.meb.gov.tr 
Milli Eğitim Bakanlığı. (2005). Matematik dersi öğretim programı ve kılavuzu (6-8. Sinıflar). Ankara: Milli Eğitim Basımevi.

National Council of Teachers of Mathematics. (2000). Principles and standards for school mathematics. Reston: NCTM Publications.

National Council of Teachers of Mathematics. (1989). Curriculum and evaluation standarts for school mathematics. Reston: NCTM Publications.

Otacıŏglu, S.G. (2008). Öğretmen adaylarının problem çözme becerileri ile öz güven düzeylerinin incelenmesi. Kuram ve Uygulamada Eğitim Bilimleri, 8(3), 893-923.

Özgen, K., \& Bindak, R. (2011). Lise öğrencilerinin matematik okuryazarlığına yönelik öz-yeterlik inançlarının belirlenmesi. Kuram ve Uygulamada Ĕgitim Bilimleri, 11(2), 1073-1089.

Pajares, F. (2001). Toward a positive psychology of academic motivation. The Journal of Educational Research, 95(1), 27-35.

Philips, D. C., \& Soltis, J. F. (2004). Öğrenme: perspektifler (S. Durmuş, Çev.). Ankara: Nobel Yayınevi.

Piersel, C.W., Larson, M.L., Allen, S.J., \& Imao, A.K. (1993). Self perceived effective and ineffective problem solvers' differential views of their partners' problem solving styles. Journal of Counseling and Development, 71, 528-538.

Polat, R.H., \& Tümkaya, S. (2010). Sınıf öğretmenliği öğrencilerinin düşünme ihtiyacına göre problem çözme becerilerinin incelenmesi. İlköğretim Online, 9(1), 346-360.

Polya, G. (1945). How to solve it: A new aspect of mathematical method. New York: Penguin.

Prawat, R.S. (2000). The two faces of dewey a pragmatism: Inductionism versus social constructivism. Teachers College Record, 102(4), 805-841.

Punch, K.F. (2005). Sosyal araştırmalara giriş-nicel ve nitel yaklaşımlar (D. Bayrak, H.B. Arslan \& Z. Akyüz, Çev.). Ankara: Siyasal Kitabevi.

Reusser, K., \& Stebler, R. (1997). Every word problem has a solution: The social rationality of mathematical modeling in schools. Learning and Instruction, 7(4), 309-327.

Rosenberg, M. (1989). Society and the adolescent self-image. Middletown, CT: Wesleyan University Press.

Saha, R.A., Ayub, A.F.M., \& Tarmizi, R.A. (2010). The effect of geogebra on mathematics achievement: Enlightening coordinate geometry learning. Procedia Social and Behavioral Sciences, 8, 686-693. 
Sarı Uzun, M., Yanık, C., \& Sezen, N. (2011). Öğretmen adaylarının matematik okuryazarlığ1 özyeterliklerinin incelenmesi. Hacettepe Üniversitesi Ĕ̆itim Fakültesi Dergisi, 2, 212-221.

Schmidt, S., \& Bednarz, N. (1997). Raisonnements arithmétiques et algébriques dans un contexte de résolution de problèmes: Difficultés rencontrées par les futurs enseignants. Educational Studies in Mathematics, 32(2), 127-155.

Schulz, W. (2005). Mathematics self-efficacy and student expectations: Results from PISA 2003. The Annual Meetings of the American Educational Research Association, Montreal, Canada.

Senemoğlu, N. (2009). Gelişim öğrenme ve öğretim-kuramdan uygulamaya. Ankara: Gazi Kitabevi.

Serin, O., Bulut Serin, N., \& Saygıl1, G. (2010). İlköğretim düzeyindeki çocuklar için problem çözme envanteri'nin (ÇPÇE) geliştirilmesi. İlköğretim Online, 9(2), 446458.

Sezen, G., \& Paliç, G. (2011). Lise öğrencilerinin problem çözme becerisi algılarının belirlenmesi. 2nd International Conference on New Trends in Education and Their Implications'da sunulmuş bildiri, 27-29 Nisan, Akdeniz Üniversitesi, Antalya, Türkiye.

Small, D.B., \& Hosack, J.M. (1986). Computer algebra system, tools for reforming calculus instruction. In R.G. Douglas (Ed.), Toward a lean and lively calculus, (pp. 143-155), Washington, DC: The Mathematical Association of America.

Soytürk, İ. (2001). Sınıf öğretmeni adaylarının matematik okuryazarlı̆̆ ve matematiksel problem çözmeye yönelik inançlarının araştırılması (Yayınlanmamış yüksek lisans tezi), İstanbul Üniversitesi, İstanbul.

Sugrue, B. (1995). A theory-based framework for assessing domain-spesific problemsolving ability. Educational Measurement: Issues and Practice, 14(3), 29-36.

Swings, S., \& Peterson, P. (1988). Elaborative and integrative thought processes in mathematics learning. Journal of Educational Psychology, 80(1), 54-66.

Şahin, N., Şahin, N.H., \& Heppner, P.P. (1993). Psychometric properties of the problem solving inventory in a group of turkish university students. Cognitive Therapy and Research, 17(4), 379-396.

Taşkın, D., Aydın, F., Akşan, E., \& Güven, B. (2012). Ortaöğretim öğrencilerinin problem çözmeye yönelik inanç ve öz-yeterlilik algıları ile rutin ve rutin olmayan problemlerdeki başarıları arasındaki ilişkinin incelenmesi. E-Journal of New World Sciences Academy, 7(1), 50-61. 
Taşkın Can, B., Cantürk, B., \& Öngel, S. (2005). Fen bilgisi öğretmen adaylarının fen derslerinde matematiğin kullanımına yönelik öz yeterlik inançlarının incelenmesi. Pamukkale Üniversitesi Ĕgitim Fakültesi Dergisi, 17, 47-52.

Taylan, S. (1990). Heppner'in problem çözme envanterinin uyarlama, güvenirlik ve geçerlik çalışmaları (Yayınlanmamış yüksek lisans tezi), Ankara Üniversitesi, Ankara.

Tekin, H. (2009). Ĕgitimde ölçme ve değerlendirme. (23. Baskı). Ankara: Yarg1 Yayınları.

Terzi, Ş. (2003). Altıncı sınıf öğrencilerinin kişiler arası problem çözme beceri algıları. Gazi Üniversitesi Türk Eğitim Bilimleri Dergisi, 1(2), 221-232.

The Organisation for Economic Co-Operation and Development. (2007). PISA 2006: Science competencies for tomorrow's world executive summary. Retrieved April 26, 2014 from the World Wide Web: http://www.pisa.oecd.org/dataoecd/15/13/39725224.pdf

Tutkun, Ö.E., Erdoğan, D.G., \& Öztürk, B. (2014). Levels of visual mathematics literacy self-efficacy perception of the secondary school students. Middle Eastern \& African Journal of Educational Research, 8, 19-27.

Türnüklü, E., \& Yeşildere, S. (2005). Problem, problem çözme ve eleştirel düşünme. Gazi Eğitim Fakültesi Dergisi, 25(3), 107-123.

Verschaffel, L., De Corte, E., Lasure, S., Van Vaerenbergh, G., Bogaerts, H., \& Ratinckx, E. (1999). Learning to solve mathematical application problems: A design experiment with fifth graders. Mathematical Thinking and Learning, 1(3), 195-229.

Yalçın, B., Tetik, S., \& Açıkgöz, A. (2010). Yüksekokul öğrencilerinin problem çözme becerisi algıları ile kontrol odağı düzeylerinin belirlenmesine yönelik bir araştırma. Organizasyon ve Yönetim Bilimleri Dergisi, 2(2), 19-27.

Yeşilyaprak, B. (2002). Gelişim ve öğrenme psikolojisi (12. bask1). Ankara: Pegem Akademi Yayıncılık.

Yıldırım, H. İ., \& Yalçın, N. (2008). Eleştirel düşünme becerilerini temel alan fen eğitiminin fen bilgisi öğretmen adaylarının problem çözme becerilerine etkisi. Gazi Üniversitesi Gazi Ĕ̆itim Fakültesi Dergisi, 28(3), 165-187.

Zengin, Y., \& Kutluca, T. (2011). Ortaöğretim matematik dersinde geogebra kullanımı üzerine ögretmen adaylarının görüşleri. $5^{\text {th }}$ International Computer \& Instructional Technologies Symposium, Firat University, Elazı̆̆, Turkey.

Zimmermann, W. (1991). Visual thinking in mathematics. In W. Zimmermann \& S. Cunningham (Eds.), Vizualization in teaching and learning mathematics (pp. 127137). Washington, DC: Mathematical Association of America. 